\title{
QUEEN'S
UNIVERSITY
BELFAST
}

\section{Airway surface liquid has innate antiviral activity that is reduced in cystic fibrosis}

\author{
Berkebile, A. R., Bartlett, J. A., Alaiwa, M. A., Varga, S. M., Power, U., \& McCray, P. B. (2020). Airway surface \\ liquid has innate antiviral activity that is reduced in cystic fibrosis. American Journal of Respiratory Cell and \\ Molecular Biology, 62(1), 104-111. https://doi.org/10.1165/rcmb.2018-0304OC
}

Published in:

American Journal of Respiratory Cell and Molecular Biology

Document Version:

Peer reviewed version

Queen's University Belfast - Research Portal:

Link to publication record in Queen's University Belfast Research Portal

\section{Publisher rights}

Copyright 2019, American Thoracic Society.

This work is made available online in accordance with the publisher's policies. Please refer to any applicable terms of use of the publisher.

\section{General rights}

Copyright for the publications made accessible via the Queen's University Belfast Research Portal is retained by the author(s) and / or other copyright owners and it is a condition of accessing these publications that users recognise and abide by the legal requirements associated with these rights.

Take down policy

The Research Portal is Queen's institutional repository that provides access to Queen's research output. Every effort has been made to ensure that content in the Research Portal does not infringe any person's rights, or applicable UK laws. If you discover content in the Research Portal that you believe breaches copyright or violates any law, please contact openaccess@qub.ac.uk. 


\section{Airway surface liquid has innate antiviral activity that is reduced in cystic fibrosis}

Abigail R. Berkebile ${ }^{1}$, Jennifer A. Bartlett ${ }^{2}$, Mahmoud Abou Alaiwa ${ }^{3}$, Steven M. Varga ${ }^{1,4}$, Ultan

$$
\text { F. Power }{ }^{5} \text {, Paul B. McCray, Jr., 1,2,\# }
$$

Departments of Microbiology and Immunology ${ }^{1}$, Pediatrics ${ }^{2}$, Internal Medicine ${ }^{3}$, and Pathology ${ }^{4}$, Pappajohn Biomedical Institute, Carver College of Medicine, University of Iowa, Iowa City, IA, USA

${ }^{5}$ Wellcome Wolfson Institute for Experimental Medicine, School of Medicine, Dentistry and Biomedical Sciences, Queen’s University Belfast, Northern Ireland, UK

Running title: Antiviral properties of CF and Non-CF ASL

Author contributions: Data collection and analysis: A.R.B. and J.A.B.; Experimental design and interpretation: A.R.B., J.A.B., M.A.A., P.B.M; Supplied reagents: S.M.V. and U.F.P.; Drafted manuscript: A.R.B., J.A.B., P.B.M.; Critical review of manuscript: M.A.A., S.M.V., U.F.P.

\#Address correspondence to:

Paul B. McCray, Jr., M.D.

6320 PBDB, Pappajohn Biomedical Institute

Department of Pediatrics, University of Iowa

Iowa City, IA 52242

Phone: 319-335-6844

Fax: 319-356-7776

Email: paul-mccray@uiowa.edu (P.B.M.) ${ }^{1}$

\footnotetext{
${ }^{1}$ This work was supported by National Institutes of Health grants P01 HL-51670 and P01 HL-091842 (P.B.M.), National Science Foundation Graduate Research Fellowship Grant No. 1048957 (A.R.B.), and the Roy J. Carver Charitable Trust. Additional partial support was provided by the Center for Gene Therapy for Cystic Fibrosis (National Institutes of Health P30 DK-54759) and the Cystic Fibrosis Foundation.
} 


\begin{abstract}
While chronic bacterial infections and inflammation are associated with progressive lung disease in cystic fibrosis (CF) patients, much less is known regarding the contributions of respiratory viral infections to this process. Clinical studies suggest that antiviral host defenses may be compromised in individuals with CF, and CF airway epithelia exhibit impaired antiviral responses in vitro. Here, we used the CF pig model to test the hypothesis that the antiviral activity of respiratory secretions is reduced in CF. We developed an in vitro assay to measure the innate antiviral activity present in airway surface liquid (ASL) from CF and non-CF pigs. We found that tracheal and nasal ASL from newborn non-CF pigs exhibited dose-dependent inhibitory activity against several enveloped and encapsidated viruses including Sendai virus (SeV), respiratory syncytial virus (RSV), influenza A, and adenovirus. Importantly, we found that the anti-SeV activity of nasal ASL from newborn CF pigs was significantly diminished relative to non-CF littermate controls. This diminution of extracellular antiviral defenses appears to be driven, at least in part, by the differences in $\mathrm{pH}$ between CF and non-CF ASL. These data highlight the novel antiviral properties of native airway secretions, and suggest the possibility that defects in extracellular antiviral defenses contribute to CF pathogenesis.
\end{abstract}

Key Words: cystic fibrosis, airway secretions, host defense, airway surface liquid, antiviral proteins 


\section{Introduction}

Cystic fibrosis (CF) is the most common lethal genetic disease among Caucasians, with patients exhibiting a median life expectancy in the early 40s (1). While CF is a multi-organ disease, most morbidity is caused by chronic lung disease characterized by acute and chronic bacterial infections and neutrophil-dominated inflammation (2). CF is caused by mutations in the gene encoding the cystic fibrosis transmembrane conductance regulator (CFTR) $(3,4)$, a nucleotidephosphorylation regulated anion channel that conducts $\mathrm{Cl}^{-}, \mathrm{HCO}_{3}{ }^{-}(5)$, and $\mathrm{SCN}^{-}(6)$ across epithelia. Much is still unknown about the link between CFTR dysfunction and lung disease progression.

Although CF newborns are commonly reported to have normal lungs, growing evidence indicates that airway host defenses are impaired as early as the first month after birth $(7,8)$. Studies using the CF pig model have provided insights into factors initiating CF lung disease. Newborn CF pigs lack airway inflammation, but within hours of birth their airways exhibit impaired antibacterial defenses compared to non-CF littermates (9). It was shown by several experimental approaches that this defect in antibacterial defenses can be attributed to a reduced bacterial killing activity in CF airway secretions (10), suggesting that abnormalities in the extracellular compartment contribute to this defect. These findings suggest that defective innate immunity contributes to early lung disease onset and progression.

The contribution of respiratory viral infections to CF lung disease onset and progression is not well understood. Although viral infection rates are similar between infants and children with CF 
and their non-CF counterparts (11-13), disease severity from viral infections appears to be greater in children with CF. Compared with control subjects, children with CF exhibit a greater likelihood of lower respiratory tract involvement during viral infections $(11,13)$, higher rates of hospitalization from respiratory infections (11), and significant and persistent decreases in pulmonary function after viral infection $(11,14)$. Additionally, epidemiological studies point to an important association between respiratory viral infections and bacterial colonization of the lungs in early childhood for children with CF (15-17). Increased viral loads have been observed in the lungs of RSV-infected CF children relative to infected non-CF controls, despite similar infection prevalence between the two groups (18), suggesting that host defense mechanisms for restricting viral replication may be less effective in CF lungs. This concept is further supported by in vitro studies of cultured CF and non-CF airway cells, demonstrating that several aspects of antiviral host defense, including interferon signaling and apoptotic responses to viral infection, are perturbed in CF airway epithelia (19-22).

Defensive responses to respiratory viruses are primarily mediated by the airway epithelium, a common site of virus replication and a first line of defense against inhaled microbes and other particulates. Serving as a vital barrier between the body and the external environment, the airway epithelium is home to cell-based mechanisms for recognizing and responding to viruses, including viral pattern recognition receptors and signaling pathways that initiate and amplify responses to viral pathogens. The airway epithelium is covered by an aqueous periciliary liquid bathing the cilia and mucus that traps microbes and allows for their removal from the airways, collectively termed airway surface liquid (ASL). Airway epithelia secrete a number of innate immune molecules into this ASL, including lysozyme, lactoferrin, defensins, cathelicidins, and 
many others (23). Many of these are multifunctional molecules exhibiting a diverse array of defensive functions, which can include antibacterial, antiviral, and antifungal activities; biofilm prevention; opsonization; pro/anti-inflammatory effects; inhibition of host and pathogen proteases; and chemokine activity, among other functions (reviewed (23)). In addition, dendritic cells, neutrophils, and resident alveolar macrophages are present or may be recruited to the airways to participate in antiviral defenses and act as a bridge between the innate and adaptive immune responses to viruses.

While several studies have described defects in the cellular responses of CF airway epithelia to viral pathogens, relatively little is known regarding the impact that genotype-dependent differences in the extracellular environment have on antiviral defenses. Using an assay developed to measure the native antiviral activity present in airway secretions, we found that ASL from humans and pigs exhibits innate antiviral properties toward several relevant classes of respiratory viruses. Here we use this assay to test the hypothesis that extracellular antiviral host defenses are impaired in CF. We observed reduced antiviral activity in ASL from CF pigs relative to non-CF, raising the possibility that defects in extracellular antiviral host defense may play a role in the establishment of CF lung disease.

\section{Materials and Methods}

\section{Collection and processing of airway surface liquid}

Three-week old pigs were anesthetized and tracheal secretions were stimulated using methacholine as previously described (10). Airway surface liquid (ASL) was harvested by advancing a microsampling probe (model BC-401C; Olympus Optical Co, Tokyo, Japan) 
through a pediatric bronchoscope inserted into the trachea. ASL was then collected by centrifuging at $10,000 \mathrm{x}$ g for 10 minutes, irradiated at $80 \mathrm{~Gy}$ and stored at $-80^{\circ} \mathrm{C}$. Nasal ASL was collected from humans and newborn pigs by inserting a sterile polyester-tipped applicator (Puritan Medical Products Co, Guilford, ME, USA) into each nostril for 5 minutes. Nasal ASL was collected by microcentrifugation, irradiated at $8 \mathrm{krad}$, and stored at $-80^{\circ} \mathrm{C}$ until use. Bronchoalveolar lavage (BAL) was collected from newborn CF and non-CF pigs according to previously described protocols (24).

\section{Viruses}

Viral inactivation assays were carried out using recombinant Sendai virus encoding an $e G F P$ reporter gene $(25,26)$ as well as a recombinant respiratory syncytial virus encoding green fluorescent protein (RSV-GFP) upstream of the NS1 open reading frame (27). Influenza A virus (A/Puerto Rico/8/1934) encoding the eGFP gene in the NS segment (IAV-eGFP) (28) was kindly provided by Kevin Legge (University of Iowa, Iowa City, IA, USA). Recombinant, replication incompetent adenovirus encoding eGFP (Ad-eGFP) was prepared by the University of Iowa Viral Vector Core Facility.

\section{Viral inactivation assay}

To assess dose-dependent viral inactivation by airway secretions, increasing volumes of ASL were pre-incubated for 2 hours with $10^{6}$ fluorescence forming units (ffu) of Sendai virus (SeVeGFP), 4 x $10^{5}$ plaque forming units (pfu) of respiratory syncytial virus (RSV-GFP), 2 x $10^{5}$ pfu of adenovirus (Ad-eGFP), or $10^{6} \mathrm{ffu}$ of influenza A (IAV-eGFP). Virus:ASL mixtures were then brought up to a volume of $250 \mu \mathrm{L}$ in $100 \mathrm{mM}$ HEPES buffer (pH 7.4) and applied at a MOI of 5- 
10 to appropriate cell lines: LLC-MK2 cells for SeV-eGFP, A549 cells for IAV-eGFP, and HEp2 cells for RSV-GFP and Ad-eGFP. Cells were incubated with the virus:ASL mixtures for 1 hour at $37^{\circ} \mathrm{C}$, then mixtures were removed and replaced with cell culture medium. After overnight incubation at $37^{\circ} \mathrm{C}$ and $5 \% \mathrm{CO}_{2}$, cells were harvested and GFP-positive cells in each condition quantified using a BD Accuri C6 flow cytometer (BD Biosciences, Franklin Lakes, NJ, USA). "Relative infectivity" represents the number of GFP-positive cells arising from infection with ASL-treated virus, expressed as a percentage of the number of GFP-positive cells after infection with untreated virus.

\section{Statistical analysis}

All data are presented as means \pm standard error about the mean. Statistical significance was determined using Student's t-tests or one-way ANOVA followed by Tukey's post-hoc tests, using Graphpad Prism (Version 6.02).

\section{Results}

Airway secretions exhibit antiviral activity

Tracheal (29) and nasal airway secretions $(30,31)$ have previously been shown to have broad spectrum antibacterial activity. However, the possible antiviral properties of airway secretions are less well established and, to our knowledge, have not been studied. To probe for such activity, we developed an assay to measure the innate antiviral activity of airway secretions, using nasal and tracheal ASL collected from 3-week old methacholine-stimulated pigs as a model. Porcine nasal and tracheal ASL were incubated with Sendai virus (SeV), a member of the Paramyxoviridae family of negative sense single stranded enveloped RNA viruses, for 2 hours at 
$37^{\circ} \mathrm{C}, 5 \% \mathrm{CO}_{2}$. For these studies, we used a recombinant $\mathrm{SeV}$ expressing an enhanced green fluorescent protein (eGFP) reporter (SeV-eGFP), to assess viral infection. After the 2-hour incubation period, the virus:ASL mixtures were applied to LLC-MK2 cells, a rhesus monkey kidney epithelial cell line that is permissive for SeV. After $\sim 18$ hours incubation at $37^{\circ} \mathrm{C}$, we quantified eGFP-positive cells by flow cytometry. As shown in Figure 1A, pre-incubation with porcine nasal or tracheal ASL reduced infection by SeV-eGFP in a dose-dependent manner. In time course studies with SeV-eGFP, we observed that the majority of antiviral activity occurred within the first 30 minutes of virus:ASL pre-incubation, with maximal viral inhibition consistently occurring after 2 hours of incubation (Supplemental Figure E1). For this reason, we selected a 2 hour incubation time for subsequent experiments.

Using this experimental approach, we then asked whether ASL inhibited the infectivity of other respiratory viruses. We found that porcine nasal and tracheal ASL also have inhibitory activity against the related pneumovirus, respiratory syncytial virus (RSV-GFP) (Figure 1B). Similar to the SeV-eGFP results, RSV-GFP infection was significantly reduced in the presence of nasal ASL; tracheal ASL displayed a more modest effect against this virus, with an approximate $25 \%$ reduction in RSV-GFP infection levels. We also found that, in addition to their effects against $\mathrm{SeV}$ and RSV, porcine nasal and tracheal ASL dose-dependently reduced infectivity of the orthomyxovirus, influenza A virus (IAV-eGFP) (Figure 1C) and serotype 5 adenovirus (AdeGFP) (Figure 1D). Unlike SeV, RSV, and IAV, adenovirus is an encapsidated non-enveloped DNA virus. These results suggest that ASL possesses inhibitory activity against a range of respiratory viral pathogens. 
Of interest, we noted that similar antiviral activity could be detected in airway secretions from humans. We found that human nasal ASL reduced the infectivity of SeV-eGFP (Figure 2A), RSV-GFP (Figure 2B), IAV-eGFP (Figure 2C), and Ad-eGFP (Figure 2D) in a dose-dependent manner similar to that of porcine nasal and tracheal ASL, suggesting that this property is a conserved feature of ASL. For the remainder of our studies, we selected SeV as a model virus because of its close antigenic and genetic homology to human parainfluenza virus 1 (HPIV-1). HPIV-1, along with HPIV-3, causes one-third of the lower respiratory tract infections in children under the age of 5 in the United States (32). Of note, human parainfluenza viruses are also implicated in pulmonary exacerbations in children with CF $(7,33,34)$.

To begin to characterize the antiviral activity we observed in porcine and human ASL, we tested whether the activity was heat labile. Porcine tracheal ASL was heated for 30 minutes at $56^{\circ} \mathrm{C}$, $65^{\circ} \mathrm{C}$, or $95^{\circ} \mathrm{C}$, or left on ice for 30 minutes. Heat treatment at $56^{\circ} \mathrm{C}$ is sufficient to inactivate components of the complement system, while most proteins are denatured at $95^{\circ} \mathrm{C}$; the $65^{\circ} \mathrm{C}$ treatment condition was chosen as an intermediate temperature. Heat-treated ASL samples were then incubated with SeV-eGFP for 2 hours before being used to infect LLC-MK2 cells as described above. ASL incubated at $56^{\circ} \mathrm{C}$ exhibited a modest, non-significant reduction in antiSeV activity compared to ASL incubated on ice (Figure 3A). ASL anti-SeV activity was significantly reduced when heated to $65^{\circ} \mathrm{C}$ or $95^{\circ} \mathrm{C}$, with $95^{\circ} \mathrm{C}$ treatment causing the greatest reduction in ASL antiviral activity. The heat-lability of ASL antiviral activity suggests that proteins are responsible for the activity. In addition, the partial reduction in ASL antiviral activity after incubation at $56^{\circ} \mathrm{C}$ and $65^{\circ} \mathrm{C}$ implies that multiple components contribute to the antiviral activity. 
Proteins from serum can reach the airways through transudation or, in the case of IgA, specific transcellular transport pathways. For this reason, many host defense proteins present in blood may be found in ASL or bronchoalveolar lavage (BAL) fluid. We therefore considered that proteins such as complement or immunoglobulins might contribute to the antiviral activity of ASL. To test this hypothesis, we assessed antiviral activity in serial dilutions of serum from newborn pigs using the SeV-eGFP infectivity assay. For this study, the serum was either left untreated or heat treated for 30 minutes at $56^{\circ} \mathrm{C}$ to inactivate complement. Untreated serum had potent, dose-dependent antiviral activity against SeV-eGFP (Figure 3B). However, in contrast to tracheal ASL, serum completely lost its anti-SeV activity after heating to $56^{\circ} \mathrm{C}$. Together with the ASL heat lability studies, these results suggest that the ASL antiviral components are not solely derived from serum (although we cannot exclude the possibility that serum-derived proteins make some contribution to the overall antiviral activity in ASL).

\section{ASL from CF pigs has reduced antiviral activity}

Earlier studies indicated that CF pigs have impaired antimicrobial defenses at birth, and that a relatively acidic ASL pH leads to reduced antibacterial properties of their airway secretions (29). We hypothesized that CF pig ASL would similarly have reduced antiviral activity compared to non-CF ASL. To test this, we collected nasal ASL from newborn $C F T R^{-/-}$pigs (CF pigs) and non-CF littermates $\left(\mathrm{CFTR}^{+/+}\right.$and $\left.C F T R^{+/}\right)$. As shown in Figure 4, CF pig nasal ASL exhibited significantly reduced antiviral activity against SeV-eGFP, relative to that of non-CF pig nasal ASL. This reduced antiviral activity was seen consistently throughout a range of tested volumes of ASL (Figure 4). We confirmed that newborn CF pig nasal ASL has a reduced pH compared 
to non-CF littermates (Figure 5A), in agreement with previous reports for newborn CF pig tracheal ASL (29), newborn human nasal fluid (35), airway breath condensate (36), human primary airway epithelial cells (37), and human submucosal gland secretions (38).

To test the hypothesis that the reduced ASL pH in CF impairs antiviral activity, we predicted that increasing the $\mathrm{pH}$ of CF nasal ASL would shift antiviral activity toward non-CF levels. We tested this by measuring the antiviral activity of CF and non-CF nasal ASL at 3 defined pHs (pH 6.8, 7.4, and 8.0). In contrast to the experiments with unmodified ASL shown in Figures 1-4, here the $\mathrm{pH}$ was clamped in each condition using buffer. As shown in Figure 5B, while the CF ASL continued to display a slight (non-significant) trend toward reduced antiviral activity relative to the non-CF ASL at each $\mathrm{pH}$, the genotype-dependent differences in ASL antiviral activity largely disappear when $\mathrm{pH}$ is clamped in this way.

We also addressed this hypothesis by asking whether altered $\mathrm{pH}$ might impact the antiviral functions of individual antimicrobial proteins and peptides (AMPs) with known antiviral activity in the airways. (Of note, the overall protein abundance did not differ significantly between CF and non-CF nasal ASL, Supplemental Figure E2). The human and porcine cathelicidins LL-37 and protegrin-1, human $\beta$-defensin 3 (HBD-3), and lysozyme all displayed antiviral activity against SeV-eGFP in our infectivity assay (Figure 6). Each of these peptides, except lysozyme, had activity that was increased at pH 6.8, though statistically significant differences between different pH conditions were only observed for HBD-3. Human $\beta$-defensin 2 (HBD-2) and lactoferrin did not exhibit significant antiviral activity against SeV-eGFP in this assay. 


\section{Discussion}

Here, we report that ASL from the airways of pigs and humans exhibits antiviral properties against a range of clinically relevant respiratory viruses, including RSV, influenza, and adenovirus. While it has long been recognized that airway epithelia mediate defensive responses to viral pathogens through cell-based signaling pathways, such as interferon production and inflammasome activation (39), there is less appreciation of the role that secreted proteins and peptides in the extracellular environment play in antiviral defenses. Our findings in pigs and humans suggest that - similar to what is known regarding antibacterial defenses - secretion of a suite of antiviral effector molecules into the ASL is likely a conserved mechanism forming an “antiviral shield” to protect the airways from inhaled viruses.

Based on our heat lability studies, we propose that the antiviral activity of porcine ASL is largely protein-mediated and represents the combined activities of multiple secreted factors. Antiviral properties have been described for a number of individual proteins and peptides found in human ASL, including LL-37 (40), HBD-2 (41) and HBD-3 (42), lactoferrin (43), lysozyme (44), SLPI (45), and the collectins surfactant protein A (SP-A) (46) and surfactant protein D (SP-D) (47). Several mechanisms are responsible for the antiviral actions of these proteins and peptides, including direct binding to and aggregation of viruses through interactions with lipid bilayers and/or viral glycoproteins, and in some cases disruption of viral membranes (40, 41). In contrast, lactoferrin inhibits parainfluenza virus 2 (PIV2) infection by binding to cellular proteins rather than through direct interaction with the virus (43). Additionally, airway mucins are thought to contribute to antiviral defenses by interacting with viruses in ways that impede their movement and/or prevent their uptake (48-50). Proteomic analysis indicates that many of the antimicrobial 
factors found in human airways can also be detected in porcine ASL, such as lactoferrin, lysozyme, SP-A, SP-D, SLPI, and numerous mucins including MUC1, -2, -4, -5B, -5AC, -13, 16, and -19 (51). While LL-37 is unique to humans, porcine ASL contains a related molecule, the cathelicidin protegrin-1 (51), which displays antiviral activity against several different viruses $(52,53)$. We expect that these proteins, and likely others, contribute to the broad-spectrum antiviral activity of porcine ASL.

Our studies demonstrate that this innate antiviral property of ASL is diminished in CF. This is consistent with a growing body of literature supporting the idea that antiviral defenses are impaired in CF airways. Compared with non-CF cells, CF airway epithelia have been shown to support increased replication of parainfluenza virus 3 (PIV3) (22), influenza (21), and rhinovirus $(19,20)$, and viral loads are increased in the lungs of CF mice after experimental infection with RSV (54). To date, these studies have focused on dysregulated interferon signaling, possibly as a consequence of chronic inflammation in the airway tissues that cells were derived from, as a central mechanism for this defect. In support of this, $\mathrm{Xu}$ and colleagues reported delayed production of interferon- $\beta$ in CF cells upon infection with influenza virus, along with altered expression of a number of interferon-inducible and antiviral response genes (21). Another report described blunted expression of the intracellular molecules 2',5'-oligoadenylate synthetase 1 (OAS1) and nitric oxide synthase 2 (NOS2) in CF airway epithelia, both at baseline and after infection with PIV3 (22).

Our results suggest that, in addition to this defect in the cellular interferon response, compromised antiviral activity in the extracellular compartment is also a likely contributor to 
impaired antiviral defenses in CF. Importantly, our experiments were performed using ASL from newborn CF pigs. CF pig airways lack inflammation at birth (24), and would have had minimal exposure to infectious or other immunostimulatory agents at the time of sample collection. Therefore, the observation of decreased antiviral activity in newborn airway secretions argues against the idea that this phenotype is a secondary consequence of inflammation, and instead suggests that diminished antiviral capacity is an inherent property of CF ASL.

The finding that CF pig ASL is intrinsically less antiviral than non-CF ASL echoes the observation that bacterial killing is impaired in the airway surface liquid of CF pigs (10). In the case of this bacterial killing defect, antibacterial activity can be restored by adjusting the $\mathrm{pH}$ of CF ASL to non-CF levels (10), indicating that loss of antibacterial activity in these secretions is primarily due to altered function of secreted antimicrobial proteins and peptides (AMPs) in the lower $\mathrm{pH}$ of CF ASL. In the current study, the finding that CF and non-CF nasal ASL exhibited similar antiviral activity when tested at equivalent $\mathrm{pHs}$ suggests that the disease-related reduction in $\mathrm{pH}$ is likely contributing to the reduced antiviral activity of CF ASL.

However, our experiments also suggest a somewhat more complicated picture with respect to the effect of $\mathrm{pH}$ on the antiviral activity of native secretions. In the airways, ASL $\mathrm{pH}$ is regulated by secretion of $\mathrm{HCO}_{3}{ }^{-}$and $\mathrm{H}^{+}$(55). Contrary to our hypothesis, reducing the $\mathrm{pH}$ of non-CF nasal ASL to a lower, more "CF-like” level had only a very modest effect on overall antiviral activity. Further, the effect of $\mathrm{pH}$ on the activities of individual antimicrobial molecules was variable, with some molecules (LL-37, protegrin-1, HBD-3) exhibiting increased antiviral activity at lower $\mathrm{pH}$, while others (lysozyme) were unaffected by $\mathrm{pH}$ changes. We speculate that this lack 
of consistent pH-dependence reflects the fact that the secreted antimicrobial factors in ASL inactivate bacteria and viruses by distinct mechanisms.

We note that while adjusting the $\mathrm{pH}$ in the $\mathrm{SeV}$ infectivity assay significantly diminished the magnitude of the CF/non-CF difference in antiviral activity, CF ASL still showed a slight impairment in activity (not statistically significant) with respect to non-CF ASL at all pHs tested (Figure 5B). This observation suggests that $\mathrm{pH}$ differences may provide only a partial explanation for the defect in CF secretions. It is possible that differences in the composition of CF and non-CF ASL may additionally influence antiviral activity. For example, while the overall protein abundance between CF and non-CF nasal ASL is not significantly different (Supplemental Figure E2), it is possible that CF ASL is lacking in a specific factor (or several factors) which accounts for some proportion of the antiviral activity in airway secretions. In an earlier study, no significant differences were noted in the abundances of selected AMPs (lysozyme, lactoferrin, PLUNC, SP-A) in tracheal ASL from newborn CF and non-CF pigs (10). However, it is currently unknown whether levels of other antimicrobial agents may be altered in CF secretions. Additionally, it has been reported that protease/antiprotease balance is altered in CF ASL, which could potentially impact innate immunity by causing aberrant cleavage and inactivation of secreted antiviral factors (56-58). Further study will be needed to better understand whether these additional mechanisms contribute to the reduced antiviral activity in CF ASL.

In conclusion, we found that human and porcine ASL is innately antiviral, with broad spectrum activity against representative enveloped and encapsidated respiratory viruses. Further, the 
potency of this antiviral activity is reduced in ASL from CF pigs relative to non-CF controls. These findings implicate extracellular antiviral mechanisms in defending the airways from inhaled viral pathogens, and also suggest that altered extracellular defenses may provide an advantage to invading viruses in CF airways. The activities of secreted antiviral molecules in the extracellular milieu are part of a larger, multilayered antiviral defense system, and further studies are needed to determine the overall impact of this defect in CF. It is possible that this reduction in the antiviral properties of CF airway surface liquid leads to a weakening of antiviral host defense in CF airways, which is then further impaired by chronic inflammation associated with the progression of CF lung disease. This reveals a previously underappreciated aspect of airway innate immunity and provides insight into how defects in this system may contribute to dysfunctional host defenses in CF. 


\section{Acknowledgements}

We thank Miguel Ortiz for critical review of the manuscript, and we also thank Henk Haagsman and Robert Gray for useful discussion regarding experiments. We acknowledge the staff at the University of Iowa College of Medicine and Holden Comprehensive Cancer Center Radiation and Free Radical Research (RFRR) Core for radiation services. The RFRR core facility is supported by funding from NIH P30 CA086862. 


\section{References}

1. Cohen-Cymberknoh M, Kerem E, Ferkol T, Elizur A. Airway inflammation in cystic fibrosis: Molecular mechanisms and clinical implications. Thorax 2013.

2. Bartlett J, McCray P. Cystic fibrosis and defective airway innate immunity. In: Hiemstra PS, Zaat SAJ, editors. Antimicrobial peptides and innate immunity: Springer Basel;2013. p. 275306.

3. Riordan J, Rommens J, Kerem B, Alon N, Rozmahel R, Grzelczak Z, Zielenski J, Lok S, Plavsic N, Chou J, et al. Identification of the cystic fibrosis gene: Cloning and characterization of complementary DNA. Science 1989;245(4922):1066-1073.

4. Rommens J, Iannuzzi M, Kerem B, Drumm M, Melmer G, Dean M, Rozmahel R, Cole J, Kennedy D, Hidaka N, et al. Identification of the cystic fibrosis gene: Chromosome walking and jumping. Science 1989;245(4922):1059-1065.

5. Smith J, Welsh M. Camp stimulates bicarbonate secretion across normal, but not cystic fibrosis airway epithelia. J Clin Invest 1992;89(4):1148-1153.

6. Pedemonte N, Caci E, Sondo E, Caputo A, Rhoden K, Pfeffer U, Di Candia M, Bandettini R, Ravazzolo R, Zegarra-Moran O, et al. Thiocyanate transport in resting and il-4stimulated human bronchial epithelial cells: Role of pendrin and anion channels. J Immunol 2007;178(8):5144-5153.

7. Armstrong D, Grimwood K, Carlin J, Carzino R, Hull J, Olinsky A, Phelan P. Severe viral respiratory infections in infants with cystic fibrosis. Pediatr Pulmonol 1998;26(6):371-379. 8. Khan T, Wagener J, Bost T, Martinez J, Accurso F, Riches D. Early pulmonary inflammation in infants with cystic fibrosis. Am J Respir Crit Care Med 1995;151(4):1075-1082. 
9. Stoltz D, Meyerholz D, Pezzulo A, Ramachandran S, Rogan M, Davis G, Hanfland R, Wohlford-Lenane C, Dohrn C, Bartlett J, et al. Cystic fibrosis pigs develop lung disease and exhibit defective bacterial eradication at birth. Science Translational Medicine 2010;2(29):29ra31.

10. Pezzulo AA, Tang XX, Hoegger MJ, Abou Alaiwa MH, Ramachandran S, Moninger TO, Karp PH, Wohlford-Lenane CL, Haagsman HP, van Eijk M, et al. Reduced airway surface pH impairs bacterial killing in the porcine cystic fibrosis lung. Nature 2012;487(7405):109-113. 11. Hiatt PW, Grace SC, Kozinetz CA, Raboudi SH, Treece DG, Taber LH, Piedra PA. Effects of viral lower respiratory tract infection on lung function in infants with cystic fibrosis. Pediatrics 1999;103(3):619-626.

12. Ramsey BW, Gore EJ, Smith AL, Cooney MK, Redding GJ, Foy H. The effect of respiratory viral infections on patients with cystic fibrosis. Am J Dis Child 1989;143(6):662-668. 13. van Ewijk BE, van der Zalm MM, Wolfs TF, Fleer A, Kimpen JL, Wilbrink B, van der Ent CK. Prevalence and impact of respiratory viral infections in young children with cystic fibrosis: Prospective cohort study. Pediatrics 2008;122(6):1171-1176.

14. Wang EE, Prober CG, Manson B, Corey M, Levison H. Association of respiratory viral infections with pulmonary deterioration in patients with cystic fibrosis. $N$ Engl $J$ Med 1984;311(26):1653-1658.

15. Collinson J, Nicholson KG, Cancio E, Ashman J, Ireland DC, Hammersley V, Kent J, O'Callaghan C. Effects of upper respiratory tract infections in patients with cystic fibrosis. Thorax 1996;51(11):1115-1122. 
16. Johansen HK, Hoiby N. Seasonal onset of initial colonisation and chronic infection with Pseudomonas aeruginosa in patients with cystic fibrosis in Denmark. Thorax 1992;47(2):109111.

17. Petersen NT, Hoiby N, Mordhorst CH, Lind K, Flensborg EW, Bruun B. Respiratory infections in cystic fibrosis patients caused by virus, chlamydia and mycoplasma--possible synergism with Pseudomonas aeruginosa. Acta Paediatr Scand 1981;70(5):623-628.

18. Kieninger E, Singer F, Tapparel C, Alves M, Latzin P, Tan H, Bossley C, Casaulta C, Bush A, Davies J, et al. High rhinovirus burden in lower airways of children with cystic fibrosis. Chest 2013;143(3):782-790.

19. Schogler A, Kopf BS, Edwards MR, Johnston SL, Casaulta C, Kieninger E, Jung A, Moeller A, Geiser T, Regamey N, et al. Novel antiviral properties of azithromycin in cystic fibrosis airway epithelial cells. Eur Respir J 2015;45(2):428-439.

20. Sutanto EN, Kicic A, Foo CJ, Stevens PT, Mullane D, Knight DA, Stick SM, Australian Respiratory Early Surveillance Team for Cystic F. Innate inflammatory responses of pediatric cystic fibrosis airway epithelial cells: Effects of nonviral and viral stimulation. Am J Respir Cell Mol Biol 2011;44(6):761-767.

21. Xu W, Zheng S, Goggans TM, Kiser P, Quinones-Mateu ME, Janocha AJ, Comhair SA, Slee R, Williams BR, Erzurum SC. Cystic fibrosis and normal human airway epithelial cell response to influenza a viral infection. J Interferon Cytokine Res 2006;26(9):609-627.

22. Zheng S, De BP, Choudhary S, Comhair SA, Goggans T, Slee R, Williams BR, Pilewski J, Haque SJ, Erzurum SC. Impaired innate host defense causes susceptibility to respiratory virus infections in cystic fibrosis. Immunity 2003;18(5):619-630. 
23. Bartlett JA, Fischer AJ, McCray PB, Jr. Innate immune functions of the airway epithelium. Contrib Microbiol 2008;15:147-163.

24. Stoltz DA, Meyerholz DK, Pezzulo AA, Ramachandran S, Rogan MP, Davis GJ, Hanfland RA, Wohlford-Lenane C, Dohrn CL, Bartlett JA, et al. Cystic fibrosis pigs develop lung disease and exhibit defective bacterial eradication at birth. Sci Transl Med 2010;2(29):29ra31.

25. Touzelet O, Loukili N, Pelet T, Fairley D, Curran J, Power UF. De novo generation of a non-segmented negative strand RNA virus with a bicistronic gene. Virus Res 2009;140(1-2):4048.

26. Villenave R, Touzelet O, Thavagnanam S, Sarlang S, Parker J, Skibinski G, Heaney LG, McKaigue JP, Coyle PV, Shields MD, et al. Cytopathogenesis of sendai virus in welldifferentiated primary pediatric bronchial epithelial cells. J Virol 2010;84(22):11718-11728. 27. Hallak LK, Spillmann D, Collins PL, Peeples ME. Glycosaminoglycan sulfation requirements for respiratory syncytial virus infection. J Virol 2000;74(22):10508-10513. 28. Manicassamy B, Manicassamy S, Belicha-Villanueva A, Pisanelli G, Pulendran B, Garcia-Sastre A. Analysis of in vivo dynamics of influenza virus infection in mice using a gfp reporter virus. Proc Natl Acad Sci U S A 2010;107(25):11531-11536.

29. Pezzulo A, Tang X, Hoegger M, Abou Alaiwa M, Ramachandran S, Moninger T, Karp P, Wohlford-Lenane C, Haagsman H, van Eijk M, et al. Reduced airway surface pH impairs bacterial killing in the porcine cystic fibrosis lung. Nature 2012;487(7405):109-113.

30. Cole A, Dewan P, Ganz T. Innate antimicrobial activity of nasal secretions. Infect Immun 1999;67(7):3267-3275. 
31. Cole A, Liao H, Stuchlik O, Tilan J, Pohl J, Ganz T. Cationic polypeptides are required for antibacterial activity of human airway fluid. J Immunol 2002;169(12):6985-6991.

32. Henrickson K. Parainfluenza viruses. Clin Microbiol Rev 2003;16(2):242-264.

33. Flight W, Bright-Thomas R, Tilston P, Mutton K, Guiver M, Morris J, Webb A, Jones A. Incidence and clinical impact of respiratory viruses in adults with cystic fibrosis. Thorax 2013. 34. Hiatt P, Grace S, Kozinetz C, Raboudi S, Treece D, Taber L, Piedra P. Effects of viral lower respiratory tract infection on lung function in infants with cystic fibrosis. Pediatrics 1999;103(3):619-626.

35. Abou Alaiwa M, Beer A, Pezzulo A, Launspach J, Horan R, Stoltz D, Starner T, Welsh M, Zabner J. Neonates with cystic fibrosis have a reduced nasal liquid $\mathrm{pH}$; a small pilot study. $J$ Cyst Fibros 2014;13(4):373-377.

36. Tate S, MacGregor G, Davis M, Innes J, Greening A. Airways in cystic fibrosis are acidified: Detection by exhaled breath condensate. Thorax 2002;57(11):926-929.

37. Coakley R, Grubb B, Paradiso A, Gatzy J, Johnson L, Kreda S, O'Neal W, Boucher R. Abnormal surface liquid $\mathrm{pH}$ regulation by cultured cystic fibrosis bronchial epithelium. Proc Natl Acad Sci U S A 2003;100(26):16083-16088.

38. Song Y, Salinas D, Nielson D, Verkman A. Hyperacidity of secreted fluid from submucosal glands in early cystic fibrosis. Am J Physiol Cell Physiol 2006;290(3):C741-C749.

39. Villenave R, Broadbent L, Douglas I, Lyons JD, Coyle PV, Teng MN, Tripp RA, Heaney LG, Shields MD, Power UF. Induction and antagonism of antiviral responses in respiratory syncytial virus-infected pediatric airway epithelium. J Virol 2015;89(24):12309-12318. 
40. Tripathi S, Tecle T, Verma A, Crouch E, White M, Hartshorn KL. The human cathelicidin LL-37 inhibits influenza A viruses through a mechanism distinct from that of surfactant protein D or defensins. J Gen Virol 2013;94(Pt 1):40-49.

41. Kota S, Sabbah A, Chang TH, Harnack R, Xiang Y, Meng X, Bose S. Role of human beta-defensin-2 during tumor necrosis factor-alpha/nf-kappab-mediated innate antiviral response against human respiratory syncytial virus. J Biol Chem 2008;283(33):22417-22429.

42. Hazrati E, Galen B, Lu W, Wang W, Ouyang Y, Keller MJ, Lehrer RI, Herold BC. Human alpha- and beta-defensins block multiple steps in herpes simplex virus infection. $J$ Immunol 2006;177(12):8658-8666.

43. Yamamoto H, Ura Y, Tanemura M, Koyama A, Takano S, Uematsu J, Kawano M, Tsurudome M, O'Brien M, Komada H. Inhibitory effect of bovine lactoferrin on human parainfluenza virus type 2 infection. $J$ Health Sci 2010;56(5):613-617.

44. Lee-Huang S, Huang PL, Sun Y, Huang PL, Kung HF, Blithe DL, Chen HC. Lysozyme and RNases as anti-HIV components in beta-core preparations of human chorionic gonadotropin. Proc Natl Acad Sci U S A 1999;96(6):2678-2681.

45. McNeely TB, Dealy M, Dripps DJ, Orenstein JM, Eisenberg SP, Wahl SM. Secretory leukocyte protease inhibitor: A human saliva protein exhibiting anti-human immunodeficiency virus 1 activity in vitro. $J$ Clin Invest 1995;96(1):456-464.

46. LeVine AM, Gwozdz J, Stark J, Bruno M, Whitsett J, Korfhagen T. Surfactant protein-A enhances respiratory syncytial virus clearance in vivo. J Clin Invest 1999;103(7):1015-1021. 47. Hartshorn KL, Crouch EC, White MR, Eggleton P, Tauber AI, Chang D, Sastry K. Evidence for a protective role of pulmonary surfactant protein D (SP-D) against influenza A viruses. J Clin Invest 1994;94(1):311-319. 
48. Lieleg O, Lieleg C, Bloom J, Buck CB, Ribbeck K. Mucin biopolymers as broadspectrum antiviral agents. Biomacromolecules 2012;13(6):1724-1732.

49. Peacocke J, Lotz Z, de Beer C, Roux P, Mall AS. The role of crude saliva and purified salivary mucins in the inhibition of the human immunodeficiency virus type 1 . Virol $J$ 2012;9:177.

50. Shukair SA, Allen SA, Cianci GC, Stieh DJ, Anderson MR, Baig SM, Gioia CJ, Spongberg EJ, Kauffman SM, McRaven MD, et al. Human cervicovaginal mucus contains an activity that hinders HIV-1 movement. Mucosal Immunol 2013;6(2):427-434.

51. Bartlett JA, Albertolle ME, Wohlford-Lenane C, Pezzulo AA, Zabner J, Niles RK, Fisher SJ, McCray PB, Jr., Williams KE. Protein composition of bronchoalveolar lavage fluid and airway surface liquid from newborn pigs. Am J Physiol Lung Cell Mol Physiol 2013;305(3):L256-266.

52. Guo C, Cong P, He Z, Mo D, Zhang W, Chen Y, Liu X. Inhibitory activity and molecular mechanism of protegrin-1 against porcine reproductive and respiratory syndrome virus in vitro. Antivir Ther 2015;20(6):573-582.

53. Rothan HA, Abdulrahman AY, Sasikumer PG, Othman S, Rahman NA, Yusof R. Protegrin-1 inhibits dengue ns2b-ns3 serine protease and viral replication in mk2 cells. J Biomed Biotechnol 2012;2012:251482.

54. Colasurdo GN, Fullmer JJ, Elidemir O, Atkins C, Khan AM, Stark JM. Respiratory syncytial virus infection in a murine model of cystic fibrosis. J Med Virol 2006;78(5):651-658.

55. Fischer H, Widdicombe JH. Mechanisms of acid and base secretion by the airway epithelium. J Membr Biol 2006;211(3):139-150. 
56. Gaggar A, Hector A, Bratcher PE, Mall MA, Griese M, Hartl D. The role of matrix metalloproteinases in cystic fibrosis lung disease. Eur Respir J 2011;38(3):721-727.

57. Taggart CC, Greene CM, Smith SG, Levine RL, McCray PB, Jr., O'Neill S, McElvaney

NG. Inactivation of human beta-defensins 2 and 3 by elastolytic cathepsins. $J$ Immunol 2003;171(2):931-937.

58. Twigg MS, Brockbank S, Lowry P, FitzGerald SP, Taggart C, Weldon S. The role of serine proteases and antiproteases in the cystic fibrosis lung. Mediators Inflamm 2015;2015:293053. 


\section{Figure Legends}

Figure 1. Porcine ASL has innate antiviral activity against respiratory viruses. (A) SeVeGFP, (B) RSV-GFP, (C) IAV-eGFP, or (D) Ad-eGFP, were incubated with increasing amounts of porcine tracheal or nasal ASL for 2 hours at $37^{\circ} \mathrm{C}$ and $5 \% \mathrm{CO}_{2}$. Virus:ASL mixtures were then brought up to $250 \mu \mathrm{L}$ volume in 100 mM HEPES buffer ( $\mathrm{pH} 7.4$ ) and used to infect appropriate permissive cell lines. Viral infection was quantified 24-hours post infection via flow cytometry analysis of eGFP expression. Infectivity is expressed as the number of GFP-positive cells observed in a given condition, as a percentage of the number of GFP-positive cells seen for the untreated (virus alone) condition. Results are displayed as mean \pm SE ( $n=3-4$ individual pig donors).

Figure 2. Human nasal ASL has innate antiviral activity against respiratory viruses. (A) SeV-eGFP, (B) RSV-GFP, (C) IAV-eGFP, or (D) Ad-eGFP, were incubated with increasing amounts of human nasal ASL for 2 hours at $37^{\circ} \mathrm{C}$ and $5 \% \mathrm{CO}_{2}$. Virus:ASL mixtures were then brought up to $250 \mu \mathrm{L}$ volume in $100 \mathrm{mM}$ HEPES buffer ( $\mathrm{pH}$ 7.4) and used to infect appropriate permissive cell lines. Viral infection was quantified 24-hours post infection via flow cytometry analysis of eGFP expression. Infectivity is expressed as the number of GFP-positive cells observed in a given condition, as a percentage of the number of GFP-positive cells seen for the untreated (virus alone) condition. Results are displayed as mean \pm SE ( $\mathrm{n}=3$ adult donors).

Figure 3. The antiviral activity in porcine ASL is heat labile and does not represent transudated serum components. (A) Porcine tracheal ASL was heated at $56^{\circ} \mathrm{C}, 65^{\circ} \mathrm{C}, 95^{\circ} \mathrm{C}$, or incubated on ice, for 30 minutes. After cooling to room temperature, ASL samples $(2.5 \mu \mathrm{L}$ per condition) were incubated with $10^{6} \mathrm{ffu}$ SeV-eGFP for 2 hours at $37^{\circ} \mathrm{C}, 5 \% \mathrm{CO}_{2}$. The virus:ASL mixtures were brought up to a volume of $250 \mu \mathrm{L}$ in $100 \mathrm{mM}$ HEPES buffer (pH 7.4) before 
infecting LLC-MK2 cells. Viral infection was quantified 24-hours post infection via flow cytometry analysis of eGFP expression. Infectivity is expressed as the number of GFP-positive cells observed in a given condition, as a percentage of the number of GFP-positive cells seen for the untreated (virus alone) condition. Results are presented as mean \pm SE. ( $n=3$ replicate experiments) ${ }^{*} p<0.05 ;{ }^{* * *} p<0.001$ as determined by one-way ANOVA followed by Tukey's multiple comparisons test. Only statistically significant differences are noted. (B) Porcine serum was either heat-treated at $56^{\circ} \mathrm{C}$ or left on ice for 30 minutes. The serum was then serially diluted and incubated with SeV-eGFP $\left(10^{6} \mathrm{ffu}\right)$ for 1 hour at $37^{\circ} \mathrm{C}, 5 \% \mathrm{CO}_{2}$. The samples were brought up to a volume of $250 \mu \mathrm{L}$ in Opti-MEM medium and anti-SeV activity was assessed as described in (A). Results are presented as mean \pm SE ( $n=3$ replicate experiments).

Figure 4. The innate antiviral activity of ASL from newborn CF pigs is reduced compared to non-CF pig secretions. SeV-eGFP was incubated with increasing amounts of nasal ASL from newborn $\mathrm{CF}$ and non-CF pigs for 2 hours at $37^{\circ} \mathrm{C}, 5 \% \mathrm{CO}_{2}$. The virus:ASL mixtures were then brought up to a volume of $250 \mu \mathrm{L}$ in $100 \mathrm{mM}$ HEPES buffer (pH 7.4) and used to infect LLCMK2 cells. Viral infection was quantified 24-hours post infection via flow cytometry analysis of eGFP expression. Infectivity is expressed as the number of GFP-positive cells observed in a given condition, as a percentage of the number of GFP-positive cells seen for the untreated (virus alone) condition. Results are presented as mean \pm SE. ${ }^{*} p<0.05$ for area under the curve as determined by Student's t-test. ( $\mathrm{n}=6$ non-CF, 8 CF)

Figure 5. pH dependence of antiviral activity in CF and non-CF nasal ASL. (A) The pH of newborn CF and non-CF pig nasal ASL was measured ex vivo with a Restech Dx-pH probe immediately prior to antiviral activity measurements. $(n=6$ non-CF, 8 CF) Results are presented as mean \pm SE. ${ }^{*} p<0.05$ as determined by Student's $t$-test. (B) The $\mathrm{pH}$ of newborn CF and non- 
CF nasal ASL was adjusted by mixing $1 \mu \mathrm{L}$ of each sample with $25 \mu \mathrm{L} 100$ mM HEPES buffer at $\mathrm{pH}$ 6.8, 7.4, or 8.0. The viral inactivation assay was then carried out as described in Methods (n = 16 non-CF, 13 CF). Results are presented as mean \pm SE.

Figure 6. Antiviral activity of individual host defense molecules at varying pHs. SeV-eGFP was incubated with increasing amounts of (A) human LL-37, (B) porcine protegrin-1, (C) human $\beta$-defensin 3 (HBD-3), (D) human lysozyme, (E) human $\beta$-defensin 2 (HBD-2), or (F) human lactoferrin for 2 hours at $37^{\circ} \mathrm{C}$ and $5 \% \mathrm{CO}_{2}$. Host defense proteins were suspended in $100 \mathrm{mM}$ HEPES buffers at pH 6.8, 7.4, or 8.0. After the 2 hour incubation, SeV-eGFP infectivity was determined as described in Methods. Results are presented as mean \pm SE ( $n=3$ replicate experiments). ${ }^{* *} p<0.01 ;{ }^{* *} p<0.001$ for area under the curve as determined by one-way ANOVA followed by Tukey’s multiple comparisons test. 

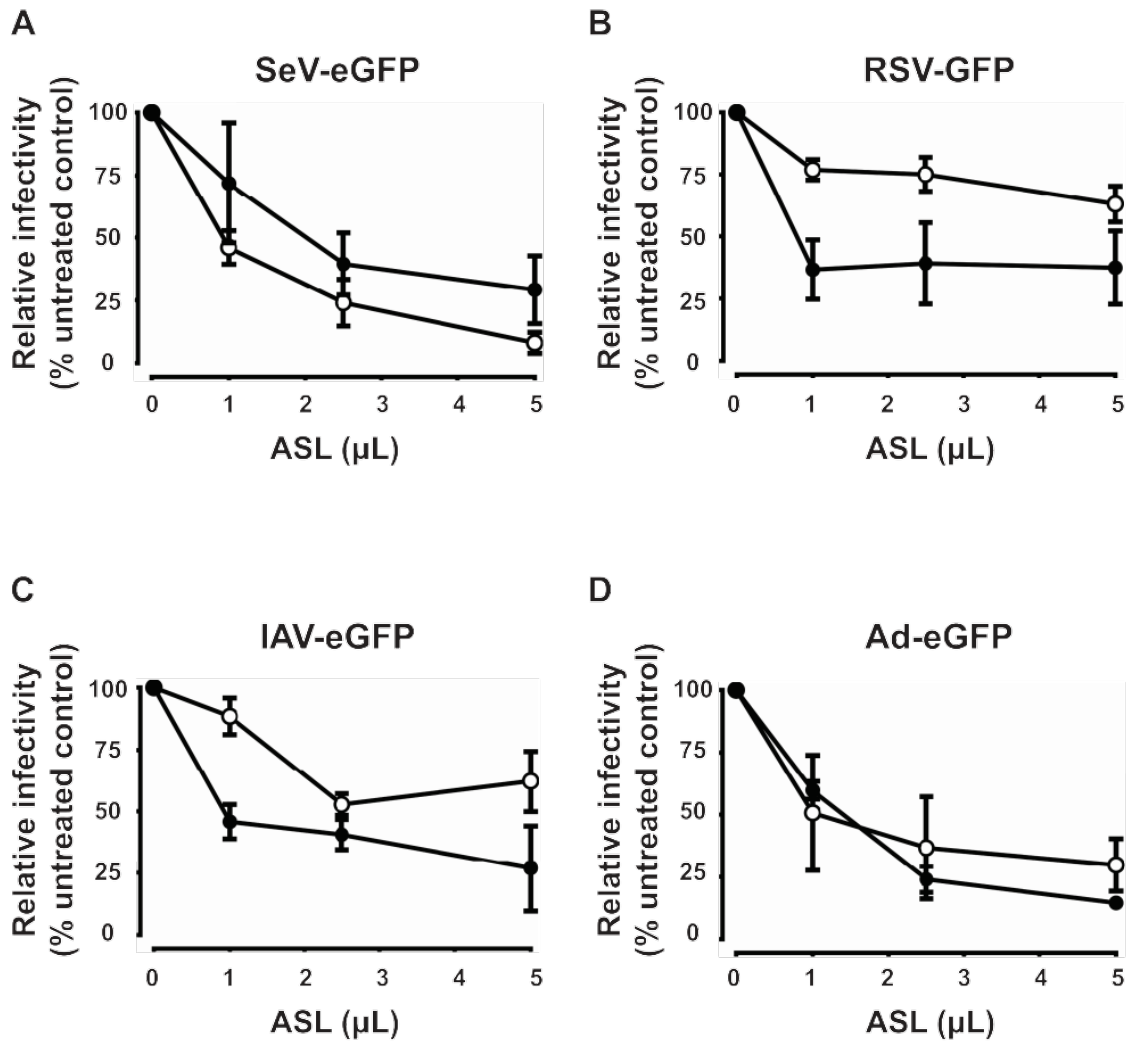

- nasal ASL $\quad-$ - tracheal ASL 

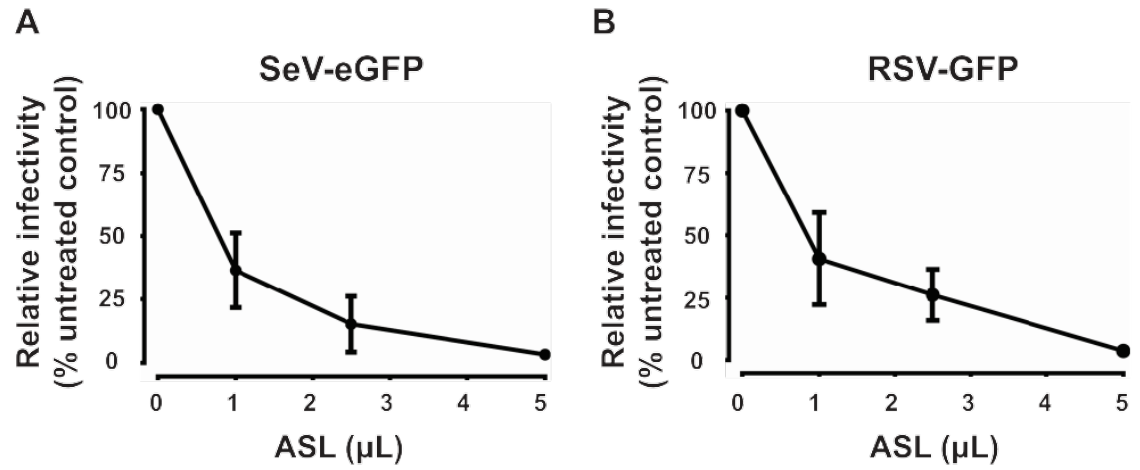

C

D
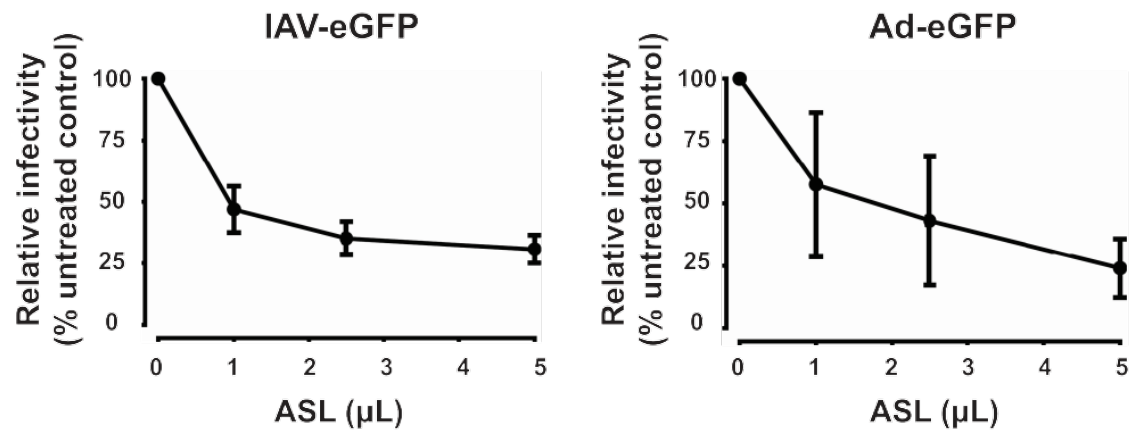

Figure 2 


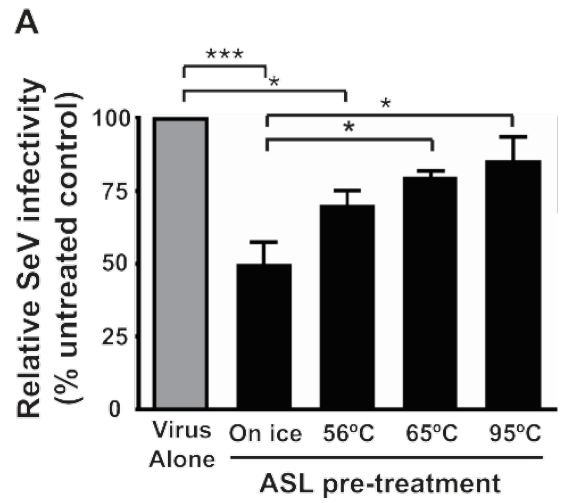

B

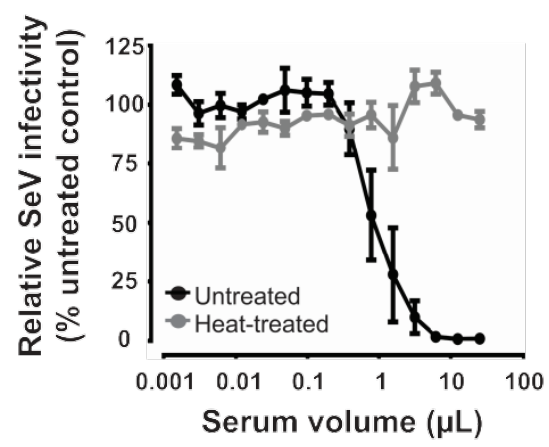

Figure 3 


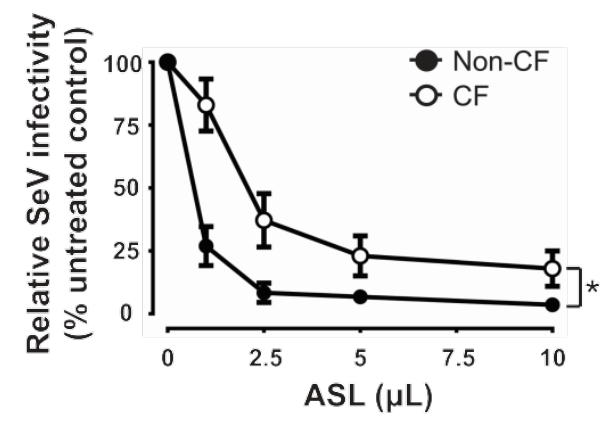

Figure 4 
A

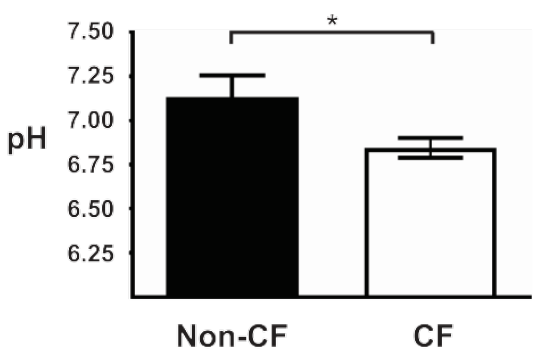

B

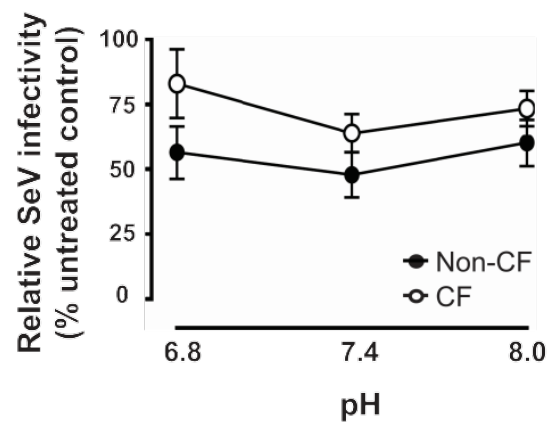

Figure 5 

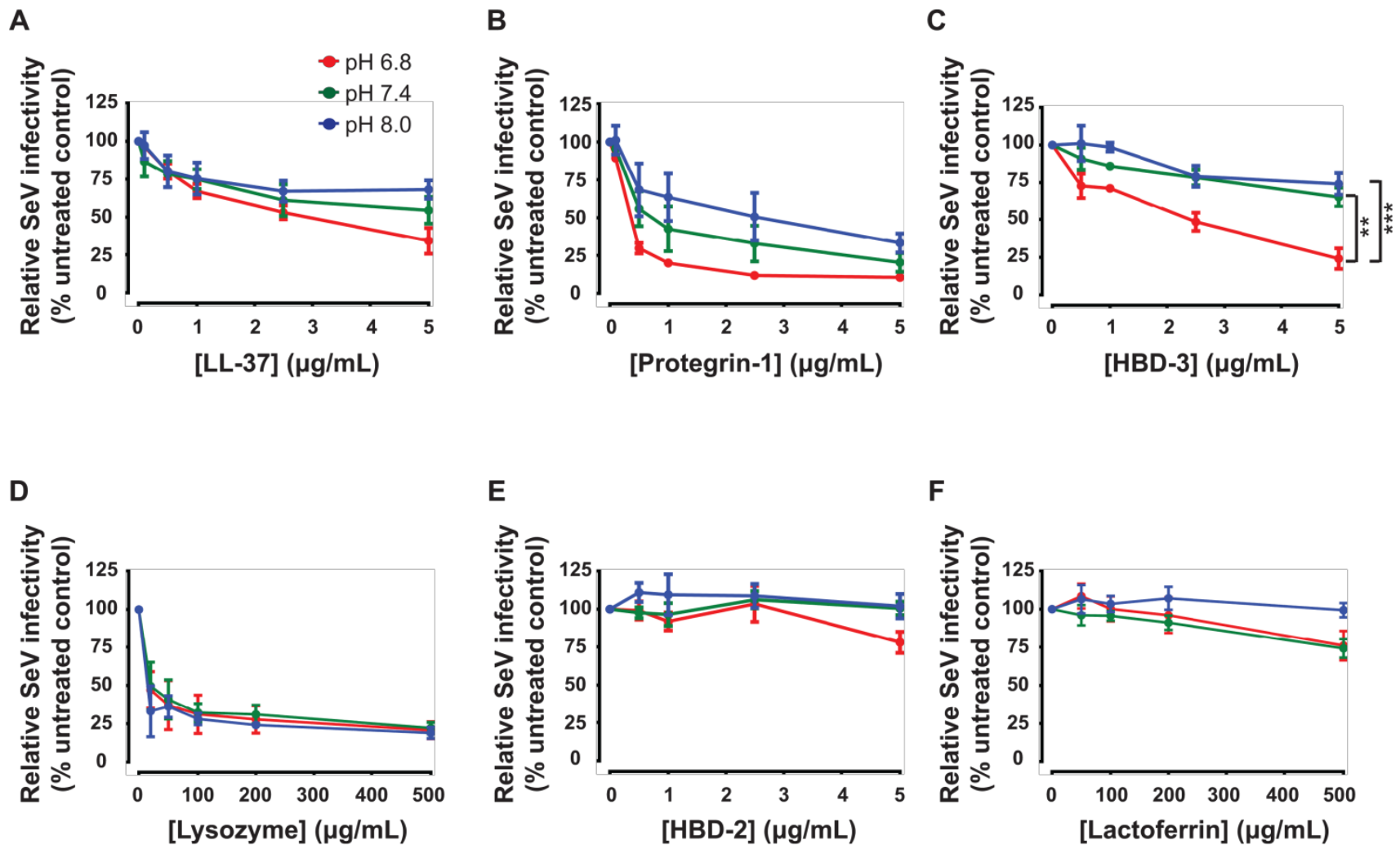

Figure 6 


\section{Online Data Supplement}

\section{Airway surface liquid has innate antiviral activity that is reduced in cystic fibrosis}

Abigail R. Berkebile, Jennifer A. Bartlett, Mahmoud Abou Alaiwa, Steven M. Varga, Ultan F. Power, Paul B. McCray, Jr. 


\section{Materials and Methods}

\section{Viruses and tissue culture}

Recombinant Sendai virus encoding the eGFP reporter gene (SeV-eGFP) $(1,2)$ was propagated by injecting the virus into the allantoic fluid of 10-day-old embryonated eggs. For infectivity assays with SeV-eGFP, LLC-MK2 cells were plated in 12-well plates at a density of $2 \times 10^{5}$ cells/well and maintained at $37^{\circ} \mathrm{C}, 5 \% \mathrm{CO}_{2}$, in Opti-MEM medium (Life Technologies, Madison, WI, USA) supplemented with 10\% fetal bovine serum and 1\% penicillin-streptomycin. Influenza A virus (A/Puerto Rico/8/1934) encoding the eGFP gene in the NS segment (IAVeGFP) (3) was kindly provided by Kevin Legge (University of Iowa, Iowa City, IA, USA). IAVeGFP infection was assessed on A549 cells that had been seeded onto 48-well plates at a cell density of $4 \times 10^{4}$ cells/well. A549 cells were maintained in DMEM (Life Technologies) containing $10 \%$ fetal bovine serum and $1 \%$ penicillin-streptomycin at $37^{\circ} \mathrm{C}, 5 \% \mathrm{CO}_{2}$.

Recombinant respiratory syncytial virus encoding green fluorescent protein (RSV-GFP) upstream of the NS1 open reading frame (4) was propagated in HEp-2 cells. Recombinant, replication incompetent adenovirus expressing eGFP (Ad-eGFP) was prepared by the University of Iowa Viral Vector Core. RSV-GFP and Ad-eGFP infectivity were assessed by infecting HEp2 cells seeded onto 48 -well plates at $4 \times 10^{4}$ cells/well. HEp-2 cells were maintained in MEM medium (Life Technologies) containing 10\% fetal bovine serum and 1\% penicillin-streptomycin, at $37^{\circ} \mathrm{C}$ and $5 \% \mathrm{CO}_{2}$.

\section{Animals}


All animal protocols were approved by the University of Iowa Animal Care and Use Committee. For collection of nasal ASL and bronchoalveolar lavage, CF and non-CF piglets were obtained from Exemplar Genetics (Sioux Center, IA, USA) and samples were collected within 12 hours of birth.

Viral inactivation assays with heat-treated ASL and porcine serum

To test for heat lability of the antiviral activity present in airway secretions, tracheal ASL was heated to $56^{\circ} \mathrm{C}, 65^{\circ} \mathrm{C}$, or $95^{\circ} \mathrm{C}$, or left on ice, for 30 minutes. For each of these conditions, $2.5 \mu \mathrm{L}$ of treated ASL was then incubated with $10^{6} \mathrm{ffu}$ SeV-eGFP for 2 hours, and our standard viral inactivation assay was carried out. Briefly, virus:ASL mixtures were brought up to a $250 \mu \mathrm{L}$ volume in $100 \mathrm{mM}$ HEPES buffer (pH 7.4) and applied to LLC-MK2 cells. Cells were incubated with the virus:ASL mixtures for 1 hour at $37^{\circ} \mathrm{C}$, then mixtures were removed and replaced with cell culture medium. After overnight incubation at $37^{\circ} \mathrm{C}$ and $5 \% \mathrm{CO}_{2}$, GFP-positive cells were quantified by flow cytometry.

To measure antiviral activity in porcine serum, serum from newborn pigs was serially diluted and incubated with $10^{6} \mathrm{ffu} \mathrm{SeV-eGFP}$ at $37^{\circ} \mathrm{C}$ for 1 hour. Samples were then brought up to 250 $\mu \mathrm{L}$ final volume in Opti-MEM (ThermoFisher Scientific,Waltham, MA, USA) and the viral inactivation assay was performed as described above. Where indicated, serum was heatinactivated by incubating at $56^{\circ} \mathrm{C}$ for 30 minutes prior to dilution in Opti-MEM.

Measurement of nasal secretion properties 
Protein concentrations of newborn CF and non-CF porcine nasal ASL samples were measured immediately after collection, using the Pierce Coomassie protein assay kit (Life Technologies). The $\mathrm{pH}$ of $\mathrm{CF}$ and non-CF nasal ASL was measured at $37^{\circ} \mathrm{C}$ and $5 \% \mathrm{CO}_{2}$, using a Dx-pH probe (Restech, San Diego, CA, USA) (5). pH measurements were made immediately prior to performing antiviral activity assays.

Effects of pH on the antiviral properties of ASL and antimicrobial proteins/peptides To assess the effect of $\mathrm{pH}$ on airway secretions, we pre-incubated $1 \mu \mathrm{L}$ of $\mathrm{CF}$ or non-CF nasal ASL with $25 \mu \mathrm{L} 100 \mathrm{mM}$ HEPES buffer at pH 6.8, 7.4, or 8.0 for 5 minutes. SeV-eGFP (10 $\left.{ }^{6} \mathrm{ffu}\right)$ was then added to the buffered ASL and incubated for 2 hours at $37^{\circ} \mathrm{C}, 5 \% \mathrm{CO}_{2}$. After this 2 hour incubation, the volume of each mixture was brought up to $250 \mu \mathrm{L}$ with $100 \mathrm{mM}$ HEPES buffer at the appropriate $\mathrm{pH}(6.8,7.4$, or 8.0$)$, and the ASL:virus mixtures were used to infect LLC-MK2 cells as described previously.

To investigate the antiviral activity of specific antimicrobials, the $\mathrm{SeV}$ inactivation assay was performed as described above, using increasing amounts of human LL-37 (Anaspec, Fremont, CA, USA), porcine protegrin-1 (Anaspec), recombinant human beta-defensin 2 (HBD2) (PeproTech, Rocky Hill, NJ, USA), HBD3 (PeproTech), recombinant human lysozyme (SigmaAldrich, St. Louis, MO, USA), and human lactoferrin (Sigma-Aldrich) in 100 mM HEPES buffer at $\mathrm{pH} 6.8,7.4$, or 8.0 . 


\section{References}

E1. Touzelet O, Loukili N, Pelet T, Fairley D, Curran J, Power UF. De novo generation of a non-segmented negative strand rna virus with a bicistronic gene. Virus Res 2009;140(1-2):40-48. E2. Villenave R, Touzelet O, Thavagnanam S, Sarlang S, Parker J, Skibinski G, Heaney LG, McKaigue JP, Coyle PV, Shields MD, et al. Cytopathogenesis of sendai virus in welldifferentiated primary pediatric bronchial epithelial cells. J Virol 2010;84(22):11718-11728.

E3. Manicassamy B, Manicassamy S, Belicha-Villanueva A, Pisanelli G, Pulendran B, Garcia-Sastre A. Analysis of in vivo dynamics of influenza virus infection in mice using a gfp reporter virus. Proc Natl Acad Sci U S A 2010;107(25):11531-11536.

E4. Hallak LK, Spillmann D, Collins PL, Peeples ME. Glycosaminoglycan sulfation requirements for respiratory syncytial virus infection. $J$ Virol 2000;74(22):10508-10513.

E5. Pezzulo AA, Tang XX, Hoegger MJ, Abou Alaiwa MH, Ramachandran S, Moninger TO, Karp PH, Wohlford-Lenane CL, Haagsman HP, van Eijk M, et al. Reduced airway surface ph impairs bacterial killing in the porcine cystic fibrosis lung. Nature 2012;487(7405):109-113. 


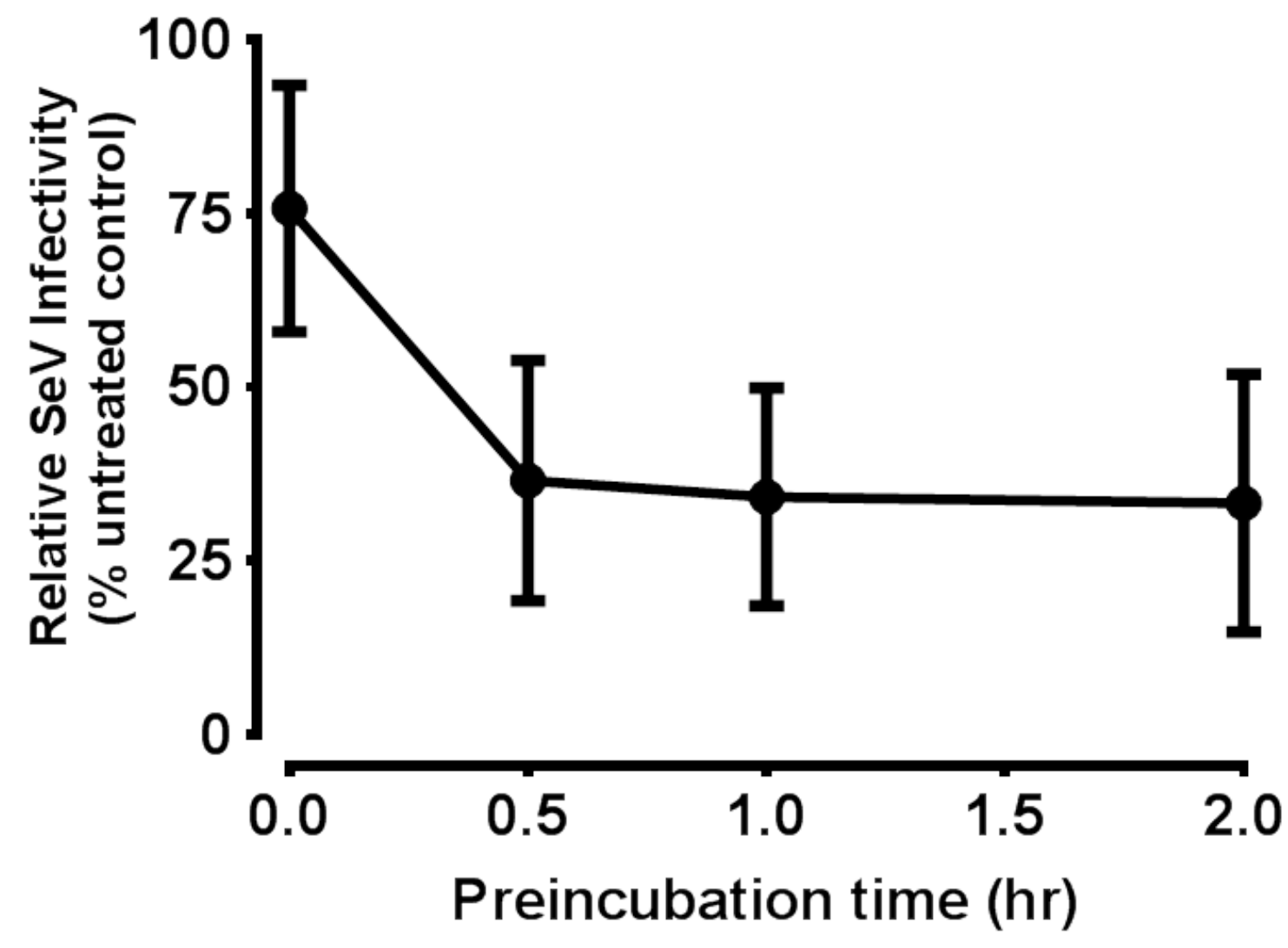

Supplemental Figure E1. Time dependence of anti-SeV activity in porcine nasal ASL. SeVeGFP $\left(10^{6} \mathrm{ffu}\right)$ was pre-incubated with $2.5 \mu \mathrm{L}$ porcine nasal ASL for $0,0.5,1$, or 2 hours at $37^{\circ} \mathrm{C}, 5 \% \mathrm{CO}_{2}$. Virus:ASL mixtures were then brought up to $250 \mu \mathrm{L}$ volume in $100 \mathrm{mM}$ HEPES buffer (pH 7.4) and used to infect LLC-MK2 cells. SeV-eGFP infectivity was quantified 24 hours post infection via flow cytometry analysis of eGFP expression. Infectivity is expressed as the eGFP fluorescence for a given condition as a percentage of the fluorescence seen for the untreated (virus alone) condition. Results are shown as mean \pm SE for samples collected from 3 individual pigs. 


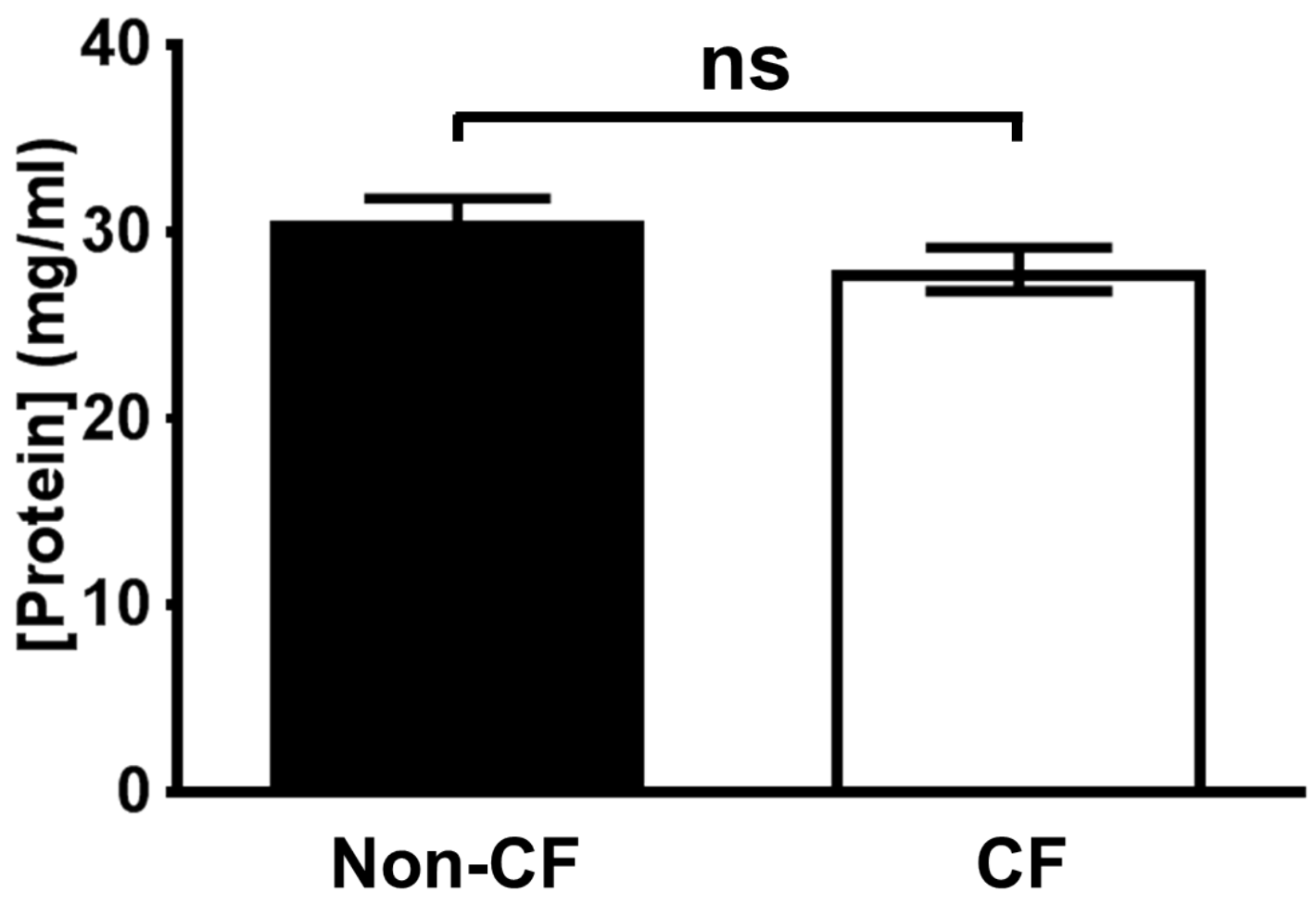

Supplemental Figure E2. Total protein concentrations in newborn CF and non-CF pig nasal secretions. Protein concentrations were measured using the Pierce Coomassie protein assay kit. ( $\mathrm{n}=11 \mathrm{non}-\mathrm{CF}, 13 \mathrm{CF}$ ) Results shown as mean $\pm \mathrm{SE}$. $\mathrm{ns}=$ not statistically significant as determined by Student's $t$-test 